STREET CORNER SECRETS 
NEXT WAVE: New Directions in Women's Studies

A series edited by

Inderpal Grewal,

Caren Kaplan, and

Robyn Wiegman 


\title{
STREET CORNER SECRETS
}

SEX, WORK, and MIGRATION in the CITY of MUMBAI

\author{
SVATI P. SHAH
}


(C) 2014 Duke University Press

All rights reserved

Printed in the United States of America on acid-free paper $\infty$ Designed by Heather Hensley

Typeset in Chaparral Pro by Copperline Book Services, Inc.

Library of Congress Cataloging-in-Publication Data

Shah, Svati Pragna

Street corner secrets : sex, work, and migration in the city of Mumbai / Svati P. Shah.

pages $\mathrm{cm}$-(Next wave : new directions in women's studies) Includes bibliographical references and index.

ISBN 978-o-8223-5689-9 (cloth : alk. paper)

ISBN 978-o-8223-5698-1 (pbk. : alk. paper)

1. Prostitutes-India-Mumbai. 2. Prostitution-IndiaMumbai. 3. Rural-urban migration-India-Mumbai.

4. Women-Employment-India-Mumbai. I. Title.

II. Series: Next wave.

HQ240.M86.S43 2014

$306.740954 ' 792-\mathrm{dc} 23$

2014000765

Cover image by Chitra Ganesh 
To Sojar Bai, who talked to me for no good reason, to my mother, Dr. Pragna Nina Shah, and to the loving memories of Dr. Madhukar Kantitlal Shah and Dr. Sid (Uday) Madhukar Shah 
